\title{
RESULTS OF DETERMINING THE DEFORMATION CHARACTERISTICS OF A LIMESTONE-SHELL ROCK DEPENDING ON ITS ANISOTROPY
}

\author{
${ }^{1}$ Novskiy A.V., Ph.D., Professor, \\ novskiva@gmail.com, ORCID: 0000-0003-1404-348 \\ ${ }^{1}$ Bichev I.K., PhD., Assistant Professor, \\ bichev@ukr.net, ORCID: 0000-0002-3000-2600 \\ ${ }^{1}$ Novskiy V.A., Ph.D., \\ novskiva1@ gmail.com, ORCID: 0000-0003-1404-0348 \\ ${ }^{1}$ Yeresko E.G., Senior Lecturer, \\ ereskolena20@gmail.com, ORCID: 0000-0003-1946-465X \\ ${ }^{1}$ Vivcharuk V.V., Student, \\ vlad.vivcharuk@gmail.com, ORCID: 0000-0001-8690-6185 \\ ${ }^{1}$ Odessa State Academy of Civil Engineering And Architecture \\ 4, Didrihsona str., Odessa, 65029, Ukraine
}

\begin{abstract}
The anisotropic properties of soil sediments and rocks have been studied by many researchers both in Ukraine and abroad. The distinctiveness of the research object was determined by the study of the anisotropy of a number of rocks properties and soils such as deformability, strength, swelling, permeability, etc. The most important from the point of view of the lower plane calculations are the deformation and strength anisotropy, introducing changes in the stress-strain state of soil masses. As a rule, the mechanical characteristics of anisotropic soils, along the bedding significantly exceed the corresponding parameters across the bedding. The widespread use of limestone-shell rock as the foundation for buildings and structures in the Odessa region, determines the need to expand research and make appropriate recommendations for taking into account anisotropy in real calculations. The methodology and results of determining the deformation characteristics of the «saw» limestone-shell rock in the device «OISI-4» are described. The authors found that the deformation modulus of the «saw» limestone-shell rock depends both on the pressure at which it is determined and on the direction of layering. In the pressure range from 0.2 to $1.0 \mathrm{MPa}$, the deformation modulus of the studied samples across the lamination was from 58 to $28 \mathrm{MPa}$, along the lamination from 64 to $41 \mathrm{MPa}$, and at an angle of $45^{\circ}$ - from 63 to $30 \mathrm{MPa}$. Wherein the anisotropy coefficient of the load impact angle of $45^{\circ}$ in average is $1,05-1,29$, and when subjected to loading along the lamination - 0,94-1,49.
\end{abstract}

Keywords: limestone-shell rock, deformation modulus, stamp, layering, field tests, anisotropy.

Introduction. The use of limestone-shell rock as the lower plane for foundations of modern buildings and structures, the increase in technological loads and number of stories, the installation of soil anchors that accept horizontal loads requires a more complete consideration of the real properties of these soils. Experimental data of the construction properties of pontic limestones of the Odessa region are currently insufficient. Usually, in materials of surveys provide information on the uniaxial compression strength, which is determined in laboratory conditions, and there is practically no data about other strength and deformation characteristics, especially taking into account the sharp anisotropy of the environment.

Overview of recent research and publications. Numerous studies of the deformation anisotropy of soils were carried out by a number of scientists I.N. Dyusembaev [1], V.A. Filimonov [2], B.A. Sokolov [3], Yu.B. Osipov, A.I. Vaitiekunene [4], M. Oda [5], V. Miligan [6], S.G. Lehnitsky [7] and A.V. School, A. Hyder [8] and others. In most cases, these studies concerned clay soils and in some cases rocky and semi-rocky. It is established that, with horizontal

Bulletin of Odessa State Academy of Civil Engineering and Architecture, 2020, no. 78, page 152-158 
and close to it bedding, the deformation modulus in the horizontal direction $\mathrm{E}_{\text {hor. }}$ significantly exceeds the soil deformation modulus in the vertical direction $\mathrm{E}_{\mathrm{vert}}$. Under these conditions precipitation which calculated without taking into account anisotropy will turn out to be deliberately larger than the actual ones, in which case the refinement of the calculation can lead to an increase in the efficiency of the designed structures. With a steep or close to vertical angle of incidence of rocks, $\mathrm{E}_{\text {hor. }}$ may be significantly less than $\mathrm{E}_{\mathrm{vert}}$.

The effect of lamination on the mechanical properties of soils is more pronounced at angles between the directions of lamination and a horizontal surface above $45^{\circ}$. The influence of the direction of layering on compressive strength decreases with humidity decreasing and increases with increasing of clay content in soils.

Analyzing the deformation anisotropy of the rocks, the researchers explain the greatest deformability in the direction perpendicular to layering by the fact that the load perpendicular to the layering causes a general deformation consisting of deformations of the rock layers and weaker layer material than the rock. Under the action of the load along the layers, practically only the rock is deformed, having less compressibility than the interlayers.

A.K. Bugrov and A.I. Golubev considered the mixed problem of elasticity theory and soil plasticity theory. In the elastic part of the array, the dependences of the theory of elasticity of a transversely isotropic environment (plane deformation) were used; in the plastic part of the stressstrain state was described by a model of perfectly plastic environment with an associated flow law and the Mohr-Coulomb plasticity condition. Problems solved by the finite element method on a computer. A significant effect of deformation and strength anisotropy of soils on the nature of the development of the areas of limiting equilibrium at the base and on the settlement of foundations is established. A significant effect of the orientation of the isotropy plane on the nature of the stressstrain state (SSS) is revealed and it is shown that neglecting the anisotropic properties of soils can lead to noticeable errors in the estimation (SSS) of real soil bases.

Until recently, there were no parameters determining the deformability of limestone-shell rock of the Odessa region. Anisotropic properties of limestone-shell rock according to the test results across and along its bedding were studied by V.A. Novskiy, Yu.F Tugayenko. [9-11]. It has been established that the uniaxial compression strength and the structural strength value along the lamination are 1.89 and 1.52 times higher, respectively, then across the lamination. The determining parameters of such media are: layering orientation, which determines the anisotropy of the base; the nature of the contact surfaces and the degree of crystallization; shear resistance of the contact surfaces. New instruments have been developed and methods have been tested for determining the deformation properties of limestone both in laboratory and field conditions. It carried out the accumulation and processing of experimental data in order to create regional standards.

Statement of the problem. Study in laboratory conditions of the deformation properties of limestone-shell rock with stamps under the action of a load across, along and at an angle to the layering. Determination of real values of the deformation modulus of these rocks taking into account anisotropy.

Research methods. To solve the posed problems, experimental and analytical methods were used, which included standard and developed with the participation of the authors methods for determining the deformation characteristics of limestone-shell rock in laboratory conditions, as well as instruments in which conditions are created that are close to field.

Studies to determine the compressibility of limestone-shell rock and the deformation modulus were performed in the OISI-4 device, the diagram of which is shown in Fig. 1. Under the loaded central stamp of the device, which occupies only a part of the sample area, volumetric deformation of the soil occurs. Deformation of the sample occurs under conditions close to those arising from field studies.

During testing, a load equal to the natural pressure of the soil at the mark of the depth of sampling is applied to the ring and round dies. An additional load is applied to the central stamp (in steps), taking into account that the area of the central stamp is equal to $18.1 \mathrm{~cm}^{2}$, annular $-154 \mathrm{~cm}^{2}$. Based on the test results, a graph of the dependence of precipitation on pressure is built $S=f(p)$.

Bulletin of Odessa State Academy of Civil Engineering and Architecture, 2020, no. 78, page 152-158 


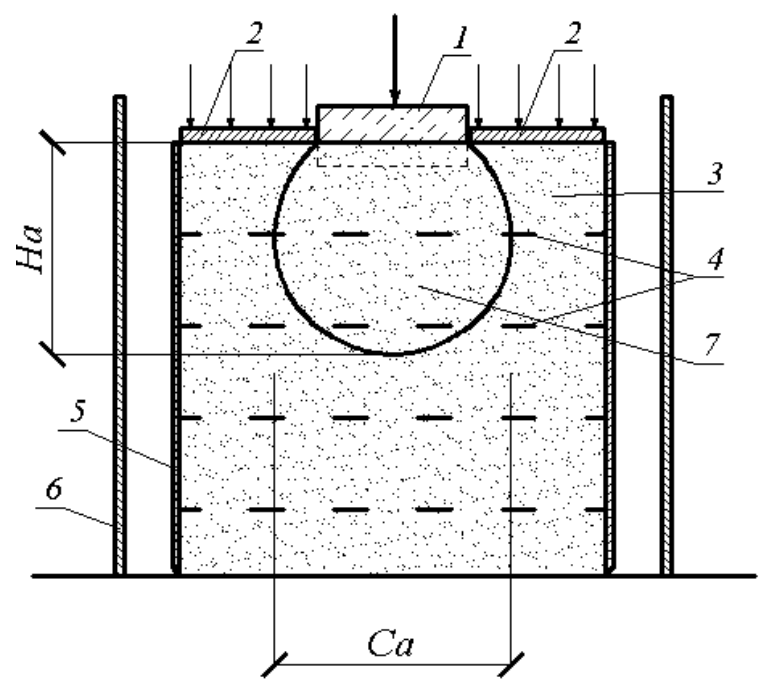

Fig. 1. Scheme of the device OISI-4:

1 - central stamp; 2 - annular stamp; 3 - soil sample; 4 - strain clamps; 5 - soil sampler ring; 6 - a container for water or a sealant; 7 - deformation zone; $\mathrm{C}_{\mathrm{a}}, \mathrm{H}_{\mathrm{a}}$ - width and depth of the deformation zone

Under the influence of an increasing pressing load, the stamp settles (Fig. 2, b), deformations develop within a limited volume of soil, the result of which is compaction and lateral expansion of the soil under its sole.

a)

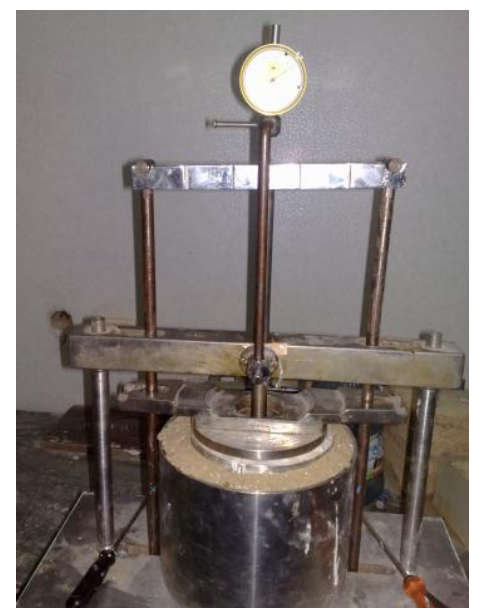

b)

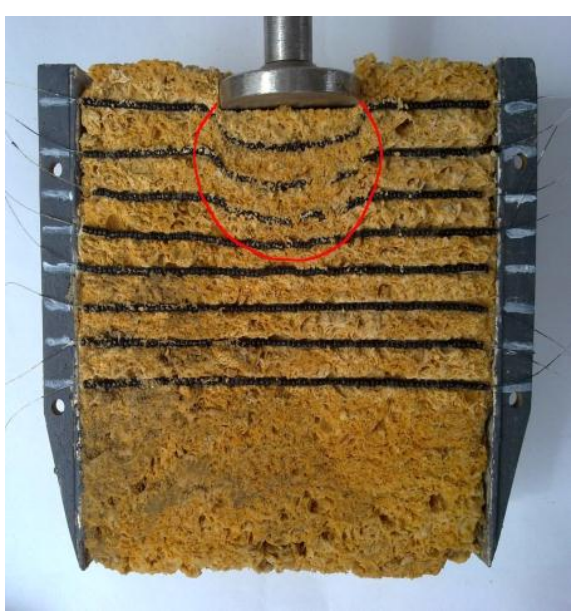

Fig. 2. The OISI-4 device (a) and a sample of limestone-shell rock after application of the load (b)

The main material and research results. The averaged test results of limestone-shell rock in seven series with different loading vectors are presented in Fig. 3.

According to the results of laboratory tests of soils with stamps, the deformation modulus is determined by the formula of F. Schleicher:

$$
\mathrm{E}=\left(1-v^{2}\right) \cdot \mathrm{K}_{\mathrm{p}} \cdot \mathrm{K}_{1} \cdot \mathrm{D} \cdot \Delta \mathrm{s} / \Delta \mathrm{p}
$$

where: $v$ - Poisson's rate, taken equal to limestone $0.28 ; \mathrm{K}_{\mathrm{p}}-$ coefficient equal to $1 ; \mathrm{K}_{1}-$ coefficient equal to 0.79 for a rigid round stamp; $\mathrm{D}$ - the diameter of the stamp, $\mathrm{cm} ; \Delta \mathrm{p}$ - increase in pressure on the stamp, MPa; $\Delta \mathrm{s}-$ the increase in the subsidence the stamp, according to $\Delta \mathrm{p}, \mathrm{cm}$. 


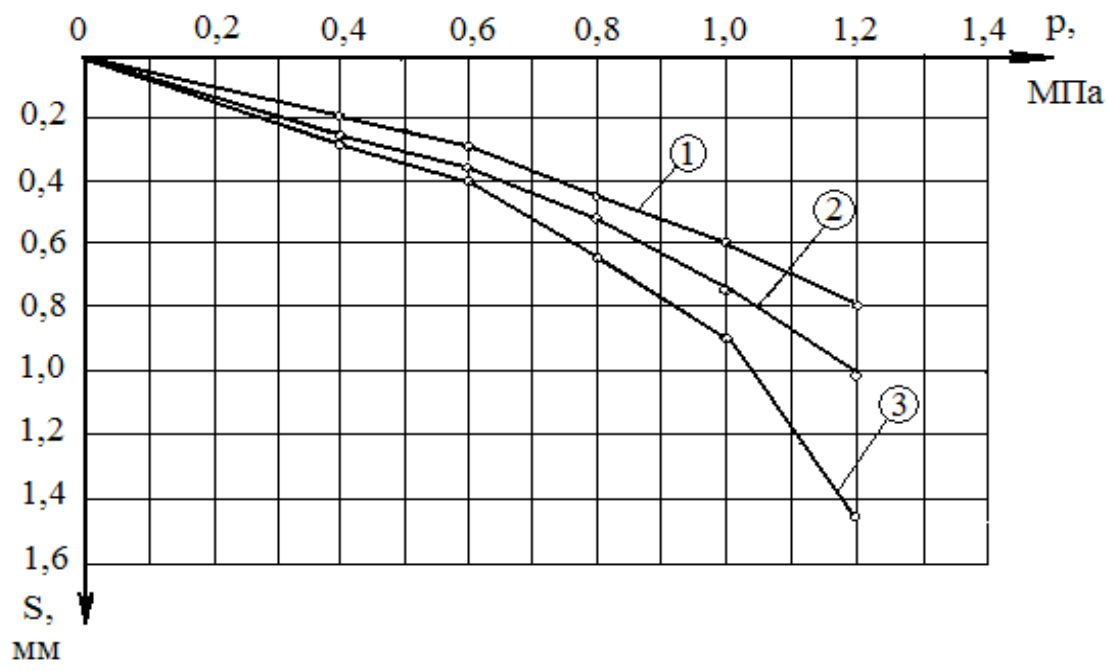

Fig. 3. Graphs of the dependence of the stamp precipitation on pressure $S=f(P)$ at natural humidity: 1 - along the layering; 2 - at an angle of $45^{\circ}$ to the layering; 3 -across layering

The values of the deformation modulus determined in the OISI-4 device at different angles of the load vector are shown in table 1, 2 and 3.

Table 1 - The results of the determination of the deformation modulus in the device OISI-4 samples, for tested across layering

\begin{tabular}{|c|c|c|c|c|c|c|}
\hline Episodes & $\begin{array}{c}\text { Within pressure } \\
\mathrm{P}, \mathrm{MPa}\end{array}$ & $\begin{array}{l}\mathrm{D}, \\
\mathrm{cm}\end{array}$ & $\begin{array}{l}\Delta \mathrm{S}, \\
\mathrm{cm}\end{array}$ & $\begin{array}{l}\Delta \mathrm{P}, \\
\mathrm{MPa}\end{array}$ & $v$ & $\begin{array}{c}\mathrm{E} \\
\mathrm{MPa}\end{array}$ \\
\hline \multirow{4}{*}{$\begin{array}{c}\text { Average } \\
\text { on } 7 \text { episodes }\end{array}$} & $0,20-0,40$ & \multirow{4}{*}{4,8} & 0,12 & \multirow{4}{*}{0,20} & \multirow{4}{*}{0,28} & 58,2 \\
\hline & $0,40-0,60$ & & 0,13 & & & 54,0 \\
\hline & $0,60-0,80$ & & 0,15 & & & 46,6 \\
\hline & $0,80-1,00$ & & 0,25 & & & 27,9 \\
\hline
\end{tabular}

Table 2 - Results of determination of the deformation modulus in the OISI- 4 device for samples tested along the layering

\begin{tabular}{|c|c|c|c|c|c|c|}
\hline Episodes & $\begin{array}{c}\text { Within pressure } \\
\mathrm{P}, \mathrm{MPa}\end{array}$ & $\begin{array}{l}\mathrm{D}, \\
\mathrm{cm}\end{array}$ & $\begin{array}{l}\Delta \mathrm{S} \\
\mathrm{cm}\end{array}$ & $\begin{array}{l}\Delta \mathrm{P} \\
\mathrm{MPa}\end{array}$ & $v$ & $\begin{array}{c}\mathrm{E} \\
\mathrm{MPa}\end{array}$ \\
\hline \multirow{4}{*}{$\begin{array}{c}\text { Average on } 7 \\
\text { episodes }\end{array}$} & $0,20-0,40$ & \multirow{4}{*}{4,8} & 0,011 & \multirow{4}{*}{0,20} & \multirow{4}{*}{0,28} & 63,5 \\
\hline & $0,40-0,60$ & & 0,009 & & & 77,5 \\
\hline & $0,60-0,80$ & & 0,016 & & & 43,6 \\
\hline & $0,80-1,00$ & & 0,017 & & & 41,0 \\
\hline
\end{tabular}

Table 3 - Results of the determination of the deformation modulus in the OISI-4 device for samples, tested at an angle of $45^{\circ}$ to layering

\begin{tabular}{|c|c|c|c|c|c|c|}
\hline Episodes & $\begin{array}{c}\text { Within pressure } \\
\mathrm{P}, \mathrm{MPa}\end{array}$ & $\begin{array}{c}\mathrm{D}, \\
\mathrm{cm}\end{array}$ & $\begin{array}{c}\Delta \mathrm{S}, \\
\mathrm{cm}\end{array}$ & $\begin{array}{c}\Delta \mathrm{P}, \\
\mathrm{MPa}\end{array}$ & $v$ & $\begin{array}{c}\mathrm{E}, \\
\mathrm{MPa}\end{array}$ \\
\hline \multirow{3}{*}{$\begin{array}{c}\text { Average on } \\
\text { 7 episodes }\end{array}$} & $0,20-0,40$ & \multirow{4}{*}{4,8} & 0,011 & & & 63,4 \\
\cline { 2 - 2 } & $0,40-0,60$ & 0,010 & \multirow{2}{*}{0,20} & \multirow{2}{*}{0,28} & 69,9 \\
\cline { 2 - 2 } & $0,60-0,80$ & & 0,014 & & & 49,9 \\
\cline { 2 - 2 } & $0,80-1,00$ & & 0,023 & & & 30,4 \\
\hline
\end{tabular}

Based on the results obtained, the deformation anisotropy coefficients of limestone-shell rock are determined as the ratio of the deformation modules along and at an angle of $45^{\circ}$ to the deformation modulus across the layering. The anisotropy coefficients at different pressure ranges are given in table. 4 . 
Table 4 - Values of the anisotropy coefficients of limestone-shell rock at different pressure ranges

\begin{tabular}{|c|c|c|c|c|c|}
\hline \multirow[b]{2}{*}{ Pressure limits } & \multicolumn{3}{|c|}{$\begin{array}{l}\text { The value of the deformation modulus E, at } \\
\text { load action: }\end{array}$} & \multirow[b]{2}{*}{$\mathbf{k}_{\mathrm{E} 0 / \mathrm{E} 90^{\circ}}$} & \multirow[b]{2}{*}{$\mathbf{k}_{\mathrm{E} 45 / \mathrm{E} 90^{\circ}}$} \\
\hline & $\begin{array}{c}\text { Across } \\
\text { layering } \\
\mathrm{E}^{90^{\circ}}\end{array}$ & $\begin{array}{c}\text { Along } \\
\text { layering } \\
\mathrm{E}^{0^{\circ}}\end{array}$ & $\begin{array}{c}\text { Under } 45^{\circ} \text { to } \\
\text { layering } \\
\mathrm{E}^{45^{\circ}}\end{array}$ & & \\
\hline $0,20-0,40$ & 58,2 & 63,5 & 63,4 & 1,09 & 1,09 \\
\hline $0,40-0,60$ & 54,0 & 77,5 & 69,9 & 1,44 & 1,29 \\
\hline $0,60-0,80$ & 46,6 & 43,6 & 49,0 & 0,94 & 1,05 \\
\hline $0,80-1,00$ & 27,9 & 41,0 & 30,4 & 1,49 & 1,09 \\
\hline
\end{tabular}

Conclusions. Numerous studies have found that the properties of soils, including rocky and semi-rocky, significantly depend on their texture (layering). The mechanical characteristics, as a rule, of anisotropic soils along the bedding significantly exceed the corresponding characteristics across the bedding.

The widespread use of limestone-shell rock as the lower plane of foundations determines the need for the development of regional studies and the preparation of appropriate recommendations for taking into account anisotropy in real calculations.

In contrast to the standard method for determining the deformation modulus, a method was applied using the OISI-4 instrument for determining the deformation characteristics developed at the Department of Foundations of the Odessa State Academy of Civil Engineering and Architecture. This device allows you to determine the deformation modulus $\mathrm{E}$ under conditions of the possibility of transverse expansion of the compressible volume of the sample. The applied technique for the technical solution is close to the method for determining the modulus of deformation by a stamp in the field conditions.

It was established that the deformation modulus of limestone-shell rock is advisable to determine in laboratory conditions using the OISI-4 device, in which the deformations of the sample are similar to deformations during field trials.

For the first time, the anisotropy coefficient was determined at an angle of $45^{\circ}$, which, depending on the load, averages 1.05-1.29. The same indicator under the action of the load along the layering is $0.94-1.49$.

The research results confirm the need to use the coefficient of deformation anisotropy of limestone-shell rock with different loading vectors.

\section{References}

[1] I.N. Diusenbaev, Vzaimodejstvie konstrukcij s anizotropnym gruntovym osnovaniem (staticheskoe sostoyanie). Almaty, 2002.

[2] V.A. Filimonov, "Issledovanie anizotropnyh prochnostnyh svojstv namyvnyh gruntov i zoly", Izvestiya VNIIG, no. 106, pp. 286-380, 1974.

[3] B.A. Sokolov, "Anizotropiya glinistyih gruntov so sloistoy teksturoy i orientirovannoy mikrostrukturoy", Gruntovedenie i inzhenernaya geologiya, M.: Izdatelstvo MGU, pp.17-22, 1979.

[4] U.B. Osipov, A.I. Vaytekunene, "Anizotropiya mehanicheskih svoystv glinistyih gruntov", Inzhenernaya geologiya, no. 4, pp. 106-112, 1979.

[5] M. Oda, I. Koishikawa, "Anisotropic fabric of sand", Proc. Of the IXthICSMFE, Tokyo, Vol. 1, pp. 235-238, 1977.

[6] K. Y. Lo, V. J. Miligan, "Shear strength properties of two stratified clays", Soil Mech. And Found. Div. Proc. ASCE., Vol. 93, pp. 1-15, 1967.

[7] S.G. Lexnickiy, Teoriya uprugosti anizotropnogo tela. M.: Nauka, 1997.

[8] A.V. Shkola, A.Xaiyder, "Anizotropiya prochnostnyih svoystv lessovyih gruntov i raschet nesuschey sposobnosti osnovaniy s ee uchetom", V. kn: Lessovyie prosadochnyie gruntyi kak osnovanie zdaniy i sooruzheniy. Kn.2 ch.2, Barnaul, 1990, pp. 212-217. 
[9] Y.F. Tugaenko, Protsessyi deformirovaniya gruntov $v$ osnovaniyah fundamentov svay $i$ svaynyih fundamentov. Odessa: «Astroprint, 2008.

[10] N.U. Kornienko, A.V. Novskiy, V.A. Novskiy, A.P. Tkalich, Y.F. Tugaenko, "Mechanical Properties of Semi-Rocks Soils and Methods of Their Determination", Proceedings of the 15th European Conference on Soil Mechanics and Geotechnical Engineering, Part 1, Athens, p. 43-49, 2011.

[11] A.V. Novskiy, V.A. Novskiy, Y.F. Tugaenko, Izvestnyak-rakushechnik. Issledovanie $i$ ispolzovanie v kachestve osnovaniya fundamentov. Astroprint: Odessa, 2014.

\title{
РЕЗУЛЬТАТИ ВИЗНАЧЕННЯ ДЕФОРМАЦЙНИХ ХАРАКТЕРИСТИК ВАПНЯКУ-ЧЕРЕПАШНИКУ $З$ УРАХУВАННЯМ ЙОГО АНІЗОТРОПІЇ
}

\author{
${ }^{1}$ Новский О.В., к.т.Н., професор, \\ novskiva@gmail.com, ORCID: 0000-0003-1404-0348 \\ ${ }^{1}$ Бічев І.К., к.Т.Н., доцент, \\ bichev@ukr.net, ORCID: 0000-0002-3000-2600 \\ ${ }^{1}$ Новський В.О., к.Т.н., \\ novskiva1@gmail.com, ORCID: 0000-0003-1404-0348 \\ ${ }^{1}$ Сресько О.Г., ст. викладач, \\ ereskolena20@gmail.com, ORCID: 0000-0003-1946-465X \\ ${ }^{1}$ Вивчарук В.В., магістр, \\ vlad.vivcharuk@gmail.com, ORCID: 0000-0001-8690-6185 \\ ${ }^{1}$ Одеська державна академія будівниитва і архітектури, \\ вул. Дідріхсона, 4, м. Одеса, 65029, Україна
}

Анотація. Анізотропні властивості грунтових відкладень і гірських порід вивчалися багатьма дослідниками, як в Україні, так і за кордоном. У більшості випадків ці дослідження стосувалися глинистих грунтів i, в окремих випадках, скельних і напівскельних. Встановлено, що властивості грунтів, в тому числі скельних і напівскельних, істотно залежать від їх текстури (шаруватості). Механічні характеристики, як правило, анізотропних грунтів уздовж шаруватості значно перевищують відповідні показники поперек шаруватості. Широке використання в даний час вапняку-черепашнику, як основи фундаментів будівель і споруд в Одеському регіоні, визначає необхідність розширення досліджень і складання відповідних рекомендацій з обліку анізотропії в реальних розрахунках.

Однією 3 актуальних завдань $є$ дослідження в лабораторних умовах деформаційних властивостей вапняку-черепашнику штампами при дії навантаження поперек, уздовж і під кутом до шаруватості, оскільки параметри, що визначають деформативність вапнякучерепашнику Одеського регіону, до недавнього часу були відсутні. Викладено методику і результати визначення деформаційних характеристик «пильного» вапняку-черепашнику. На відміну від стандартного методу для визначення модуля деформації була застосована методика 3 використанням розробленого на кафедрі основ і фундаментів Одеської державної академії будівництва та архітектури, приладу OICI-4 по визначенню деформаційних характеристик. Цей прилад дозволяє визначити модуль деформації Е в умовах можливості поперечного розширення об'єму зразка, що стискається. Застосована методика по технічному рішенню близька до методу визначення модуля деформації штампом в польових умовах.

Авторами встановлено, що модуль деформації «пильного» вапняку-черепашнику залежить як від тиску, при якому він визначається, так і від напрямку шаруватості. В інтервалі тисків від 0,2 до 1,0 МПа модуль деформації досліджених зразків поперек шаруватості складав від 58 до $28 \mathrm{MПа,} \mathrm{вздовж} \mathrm{шаруватості} \mathrm{від} 64$ до $41 \mathrm{MПа,} \mathrm{а} \mathrm{під} \mathrm{кутом} \mathrm{45^{ \circ }}$ - від 63 до 30 МПа. При цьому коефіцієнт анізотропії при дії навантаження під кутом $45^{\circ}$ в середньому становить 1,05-1,29, а при дії навантаження вздовж шаруватості - 0,94-1,49.

Результати досліджень підтверджують необхідність дифференцируемого використання коефіцієнта деформаційної анізотропії вапняку-черепашнику при різних векторах завантаження. 
Ключові слова: вапняк-черепашник, модуль деформації, штамп, шаруватість, польові випробування, анізотропія.

\title{
РЕЗУЛЬТАТЫ ОПРЕДЕЛЕНИЯ ДЕФОРМАЦИОННЫХ ХАРАКТЕРИСТИК ИЗВЕСТНЯКА-РАКУШЕЧНИКА С УЧЕТОМ ЕГО АНИЗОТРОПИИ
}

\author{
${ }^{1}$ Новский А.В., к.т.н., профессор, \\ novskiva@gmail.com, ORCID: 0000-0003-1404-0348 \\ ${ }^{1}$ Бичев И.К., к.т.н., доцент, \\ bichev@ukr.net, ORCID: 0000-0002-3000-2600 \\ ${ }^{1}$ Новский В.А., к.Т.Н., \\ novskiva1 @gmail.com, ORCID: ORCID: 0000-0003-1404-0348 \\ ${ }^{1}$ Ересько Е.Г., ст. преподаватель, \\ ereskolena20@gmail.com, ORCID: 0000-0003-1946-465X \\ ${ }^{1}$ Вивчарук В.В., магистр, \\ vlad.vivcharuk@gmail.com, ORCID: 0000-0001-8690-6185 \\ ${ }_{1}^{1}$ Одесская государственная академия строительства и архитектуры, \\ ул. Дидрихсона, 4, г. Одесса, 65029, Украина
}

\begin{abstract}
Аннотация. Анизотропные свойства грунтовых отложений и горных пород изучались многими исследователями, как в Украине, так и за рубежом. В большинстве случаев эти исследования касались глинистых грунтов и, в отдельных случаях, скальных и полускальных. Установлено, что свойства грунтов, в том числе скальных и полускальных, существенно зависят от их текстуры (слоистости). Механические характеристики, как правило, анизотропных почв вдоль слоистости значительно превышают соответствующие показатели поперек слоистости. Широкое использование в настоящее время известняка-ракушечника, как основания фундаментов зданий и сооружений в Одесском регионе, определяет необходимость расширения исследований и составления соответствующих рекомендаций по учету
\end{abstract} анизотропии в реальных расчетах.

Одной из актуальных задач является исследование в лабораторных условиях деформационных свойств известняка-ракушечника штампами при воздействии нагрузки поперек, вдоль и под углом к слоистости, поскольку параметры, определяющие деформативность известняка-ракушечника Одесского региона, до недавнего времени отсутствовали. Изложена методика и результаты определения деформационных характеристик «пильного» известняка-ракушечника. В отличие от стандартного метода для определения модуля деформации была применена методика с использованием разработанного на кафедре оснований и фундаментов Одесской государственной академии строительства и архитектуры, прибора ОИСИ-4 по определению деформационных характеристик. Этот прибор позволяет определить модуль деформации Е в условиях возможности поперечного расширения объема образца. Примененная методика по техническому решению близка к методу определения модуля деформации штампом в полевых условиях.

Авторами установлено, что модуль деформации «пильного» известняка-ракушечника зависит как от давления, при котором он определяется, так и от направления слоистости. В интервале давлений от 0,2 до 1,0 МПа модуль деформации исследованных образцов поперек слоистости составлял от 58 до $28 \mathrm{MПа,} \mathrm{вдоль} \mathrm{слоистости} \mathrm{от} 64$ до $41 \mathrm{MПа,} \mathrm{а} \mathrm{под} \mathrm{углом} 45^{\circ}-$ от 63 до 30 МПа. При этом коэффициент анизотропии при воздействии нагрузки под углом $45^{\circ}$ в среднем составляет 1,05-1,29, а при воздействии нагрузки вдоль слоистости - 0,94-1,49.

Результаты исследований подтверждают необходимость дифференцированного использования коэффициента анизотропии известняка-ракушечника при разных векторах загрузки.

Ключевые слова: известняк-ракушечник, модуль деформации, штамп, слоистость, полевые испытания, анизотропия.

Стаття надійшла до редакції 27.01.2020

Bulletin of Odessa State Academy of Civil Engineering and Architecture, 2020, no. 78, page 152-158 